\section{Adenomyoma of Stomach}

Brit. med. F., 1967, 3, 843

Gastric adenomyoma is a rare cause of pyloric obstruction. It was first recognized radiologically as a possible cause of benign pyloric stenosis by Campbell (1949). The histological features of the tumour were first described by Magnus-Alsleben (1903), who reported five cases discovered incidentally at necropsy. Since then 23 additional cases have been published. Four cases examined radiologically showed evidence of a benign pyloric lesion (Wass, McCloskey, and Sullivan, 1951 ; Cimmino, 1955 ; Goldberg and Margulis, 1966). Two of the standard radiological textbooks do not mention adenomyoma as a cause of pyloric obstruction (Shanks and Kerley, 1958 ; Lumsden and Truelove, 1965). The lesion is important clinically because of its histological similarity to heterotopic pancreatic tissue, which it may also mimic radiologically.

\section{CAse Report}

A 39-year-old housewife presented with a 10-year history of recurrent attacks of epigastric pain and vomiting. Pain was not relieved by antacids, was unrelated to meals, and was made worse when she ate meat and fatty foods. Her appetite was good except during the intermittent vomiting attacks. There was no history of shoulder pain, haematemesis, melaena, or weight loss. Clinical examination revealed some epigastric tenderness, but no palpable masses or other abnormality.

Investigations.-Haemoglobin 13.4 g./100 ml.; white cell count $4,700 \mathrm{cu} . \mathrm{mm}$. ; erythrocyte sedimentation rate $10 \mathrm{~mm}$. in one hour ; blood group $\mathbf{A}$ rhesus-positive. Barium meal: a small ulcer niche was demonstrated on the mid-third of the lesser curve of the stomach; there was some delay in initial gastric emptying; there was a constant narrowing of the pyloric antrum with two persistent niches of barium; a pyloric filling defect was constant despite changes of position and palpation; peristalsis was normal in the area ; the oesophagus and duodenal cap were normal. The appearances were unchanged on re-examination after one month.

Operative Findings.-A firm mass was palpable in the anterior wall of the pyloric antrum. A small benign lesser-curve ulcer was present. The distal two-thirds of the stomach was resected and a gastroduodenal anastomosis performed. Recovery was uneventful.

Pathological Findings.-There was marked narrowing of the pyloric antrum by a thickening of the submucosa and muscle for $3 \mathrm{~cm}$. The submucosa was firm and grey, and up to $0.5 \mathrm{~cm}$. thick. The muscle coat in the area was $1.2 \mathrm{~cm}$. thick. Macroscopic spaces were visible in the submucosa and underlying part of the muscle coat. The histological appearances were those of an adenomyoma. Examination of various areas of the tumour showed areas of Brunner's glands and ducts lined by columnar epithelium surrounded by connective tissue and muscle bundles. A track was seen running from the submucosa into the gastric lumen. The lesser-curve ulcer was small, chronic, and benign.

\section{COMMENT}

Benign tumours of the stomach are rare and present with a variety of symptoms.

This patient's symptoms were suggestive of peptic ulcer with intermittent pyloric obstruction. The previously reported cases of adenomyoma have had various symptoms, including vague indigestion, epigastric discomfort, and chest pain. An epigastric tumour was palpable in one case (Gruzdeff, 1909). Adenomyoma has been described in association with infantile hypertrophic pyloric stenosis (Wass et al., 1951). The lesion has always been found on the anterior wall of the pyloric antrum. On barium meal examination four cases showed pyloric narrowing and a constant filling defect.
A central umbilication, often described as being typical of leiomyoma or neurofibroma, which may also occur in the pylorus, was found in one case (Cimmino, 1955).

The pyloric niche in the present case corresponded to the track demonstrated histologically. Ducts opening into the pyloric antrum have not been previously described in adenomyoma and have been referred to as being typical of heterotopic pancreatic tissue (Lapidari, 1937). There is a close relation between these two lesions. Both originate from primordial epithelial buds which may develop in varying degrees of differentiation, resulting in the eventual histological spectrum of adenomyoma, aberrant pancreas, and hyperplasia of Brunner's glands (Clarke, 1940). The essential histological feature is the presence of differentiated and undifferentiated glandular tissue in the submucosa and mucosa of the pyloric antrum (Stewart and Taylor, 1925). The lesion is classified according to which cell type predominates: undifferentiated glandular epithelium and muscle whorls in adenomyoma, Brunner's type differentiated epithelium, or pancreatic type acini. Aberrant pancreas is the commonest of these. It is seen more often in males (Copleman, 1963) and produces pyloric obstruction in $25 \%$ of cases which occur in adults (Palmer, 1951). It is usually intramural and almost half the lesions are in the distal third of the stomach.

Apart from pyloric obstruction due to peptic ulceration with pylorospasm or fibrosis and the characteristic deformity due to pyloroplasty, there are many benign causes of pyloric stenosis. A pyloric mucosal polyp usually has a pedicle and is mobile. A congenital mucosal diaphragm, due to failure of canalization of the embryonic foregut (Conway, 1965), and the focal type of hypertrophic pyloric stenosis, the features of whicn have been reviewed by Seaman (1966), may both cause eccentric pyloric narrowing.

Much rarer lesions producing pyloric narrowing include eosinophilic gastroenteritis, which is associated with changes in the small intestine and responds to steroids (Wolf and Khilnani, 1966). Gastric sarcoidosis, tuberculosis, eosinophil granuloma, and tertiary syphilis may present with pyloric narrowing, usually in association with systemic manifestations of the disease, which assist in the diagnosis.

In the case described the lesion was thought on barium meal examination to be due to aberrant pancreas. Histology confirmed the diagnosis of gastric adenomyoma. The patient remained asymptomatic over a two-year period.

JAMES G. MCNUlTy,* M.B., F.F.R., Senior Registrar, Department of Radiology, Royal Free Hospital, London W.C.1.

* Present address: Department of Radiology, St. Thomas's Hospital, London S.E.1.

\section{REFERENCES}

Campbell, R. J. C. (1949). Brit. F. Radiol., 22, 284.

Cimmino, C. V. (1955). Radiology, 65, 73.

Clarke, B. E. (1940). Arch. Path., 30, 143.

Conway, N. (1965). Brit. med. f., 1, 970.

Copleman, B. (1963). Radiology, 81, 107.

Goldberg, H. I., and Margulis, A. R. (1966). Amer. F. Roentgenol., 96, 382.

Gruzdeff, D. A. (1909). Med. Obozr. Mosk., 71, 805.

Lapidari, M. (1937). Arch. ital. Chir., 47, 432.

Lumsden, K., and Truelove, S. C. (1965). Radiology of the Digestive System. Oxford.

Magnus-Alsleben, E. (1903). Virchows Arch. path. Anat., 173, 137.

Palmer, E. D. (1951). Medicine (Baltimore), 30, 81.

Seaman, W. B. (1966). Amer. F. Roentgenol., 96, 388.

Shanks, S. C., and Kerley, P. (1958). A Textbook of X-ray Diagnosis, vol. 3. London.

Stewart, M. J., and Taylor, A. L. (1925). F. Path. Bact., 28, 195.

Wass, F. J., McCloskey, B. J., and Sullivan, E. J. (1951). Amer. Surgn., $17,844$.

Wolf, B. S., and Khilnani, M. T. (1966). Gastroenterology, 51, 542. 